\title{
PowerPoint Presentation Technology and the Dynamics of Teaching
}

\author{
Russell J. Craig • Joel H. Amernic
}

Published online: 2 August 2006

(C) Springer Science + Business Media B.V. 2006

\begin{abstract}
This article presents a wide-ranging analysis of the use of PowerPoint technology in higher education. It addresses four overlapping issues. Has PowerPoint led to more effective learning? What impact has PowerPoint had on the dynamics of classrooms? What are some important aspects of the culture that accompanies PowerPoint? How has PowerPoint affected orality, visuality and literacy? The purpose of our article is to stimulate beneficial conversations about a prevalent educational software technology.
\end{abstract}

Key words powerpoint · technology in teaching · education

This article focuses on PowerPoint, a powerful and ubiquitous communications technology and aid to teaching and business presentations. In 2002, it was estimated that more than 400 million copies of PowerPoint were in circulation and that "somewhere between 20 and 30 million PowerPoint-based presentations are given around the globe each day" (Simons, 2005). Those numbers seem likely to have grown exponentially since then. Indeed, Parker (2001) alleged that to "appear at a meeting without PowerPoint would be unwelcome and vaguely pretentious, like wearing no shoes" (pdf version, p. 2). Further, the use of PowerPoint is so widespread in higher education institutions that for a faculty member to refrain from using PowerPoint is "sometimes seen as a mark of seniority and privilege, like egg on one's tie" (Parker, 2001, p. 6, citing a conversation with Stanford University Professor Clifford Nass).

PowerPoint has a dubious reputation. It has been described as "the Viagra of the spoken word ... [and] a wonder pill for flabby lectures" (van Jole, 2000); and as something that “...

Russel Craig received his B.Com., M.Com. and Ph.D. from the University of Newcastle, Australia. He is Professor in the National Graduate School of Management at The Australian National University.

Joel Amernic received his B.Sc., and M.B.A. from the University of Toronto, where he is a Professor in the Rotman School of Management.

Both authors are long-term collaborators with common research interests in management education, the accountability discourse of CEOs, and various aspects of corporate accounting and financial reporting, including the use of accounting data in employment relations.

R. J. Craig $(\bowtie)$

National Graduate School of Management, The Australian National University, Canberra, Australia e-mail: Russell.Craig@anu.edu.au 
turns clear thinking adults into addled-headed boobs" (Shwom \& Keller, 2003, p. 3). But, if PowerPoint is a drug, Tufte (2003a) argued it ought to be subject to a worldwide product recall, for it had "frequent, serious side effects: it induced stupidity, turned everyone into bores, wasted time, and downgraded the quality and credibility of communication" (para. 1).

PowerPoint technology has become a punching bag that Parker (2001) alleged has turned its users "into bullet-point dandies" (p. 1). It has been criticized for elevating form over content (Tufte, 2003a, b); assigned part of the cause for "a general decline in public speaking" (Nunberg, 1999, p. 330); denounced by academics and by CEOs ... for causing detrimental effects on "dialogue, interaction, and thoughtful consideration of ideas" (Cyphert, 2004, p. 80); bemoaned as a facilitator of presentations that are "often tediously long and more annoying than Microsoft's animated paperclip" (Goldkorn, 2004, para. 4); and accused of "replacing clear thought with unnecessary animations, serious ideas with ten-word bullet points, substance with tacky, confusing style" (Coursey, 2003, para. 2). Although PowerPoint promises much in terms of delivering content efficiently and offering attractive and dynamic presentations, some critics, such as Stewart (2001), allege that a frequent outcome is a vacuous monotony.

The preceding critical characterizations of PowerPoint might give the misleading impression that we are about to engage in a harangue of the type: "PowerPoint bad ... nonPowerPoint good." However, such is not the case. We simply want to go beyond the content of the usual clichéd fare of literature on PowerPoint. This is preponderantly of three major types. First, is the literature which provides technical advice on how to prepare PowerPoint presentations (e.g., Coursey, 2003; Jones, 2003; Shwom \& Keller, 2003). Second, is literature which outlines the advantages and disadvantages of PowerPoint. Much of this is in the form of PowerPoint presentations that are accessible through keyword search using Google, such as Bostock (2005)_although some appears in scholarly journals such as Jones (2003). Third, is literature which takes a titillating swipe at the ostensible evils of PowerPoint or provides an unapologetically jaundiced account of its unsurpassable virtues (e.g., Nunberg, 1999; Stewart, 2001).

It is our intent to delve more deeply into four matters that deserve reflecting upon by educators and business seminar presenters. We seek to highlight some subtle but important issues that accompany the PowerPoint phenomenon. In doing so, we invoke a wide range of scholarly literature drawn from a variety of disciplines and an array of business periodicals and website newsletters. We address four overlapping issues. First, we review scholarly literature that examines the effectiveness of PowerPoint. Second, we explore how PowerPoint presentations affect the dynamics of pedagogical settings and the general relationship between presenter and presentees. Third, we analyse important aspects of the culture that attaches to PowerPoint technology. Finally, we explore PowerPoint-related issues of visuality, orality and literacy.

This article does not offer a broadly conceived exploration of McLuhan's thesis that "the medium is the message" (McLuhan \& Fiore, 1967). We do not dwell upon Innis's (1991) ideas regarding the social nature of new technologies or upon semiotics in order to conceive PowerPoint as another dominating, socially forceful technological mediator of teaching. Although we do not focus on cataloguing how to design more effective PowerPoint slides, we draw attention to the failure of many PowerPoint presenters to ignore fundamental rhetorical principles; and we offer some advice on that matter. We do not engage in what Shwom and Keller (2003) referred to as "victimology"; that is, to make "PowerPoint the villain that oppresses its users, and almost by default absolve the presenter from taking any personal responsibility for providing significant content and communicating that content clearly" (p.15). 
In the past three decades there has been a decisive shift in the media that have been used to communicate messages in educational settings. We have gone from the era of "chalkand-talk" and occasional flip-charts to overhead transparencies and to PowerPoint slides. And, consistent with Warnick (2002), we feel it is important to recognize that any "new forms of communicating call for new ways of thinking about communication processes" (p. 264). However, it is important, as well, that we do not become "zealous ... one-eyed prophets who see only what new technologies can do and are incapable of imagining what they will undo" [italics in original] and that we offer "a dissenting voice ... to moderate the din made by the enthusiastic [technophile] multitudes" (Postman, 1993, p. 5).

In a sense, we are somewhat akin to Postman's “technological resistance fighter [who] maintains an epistemological and psychic distance from any technology, so that it always appears somewhat strange, never inevitable, never natural" (Postman, 1993, pp.183-185). We are mindful of the implicit, perhaps largely unnoticed, alteration in "human attentionstructures" (Lanham, 1993) that pervasive new technologies such as PowerPoint (and its allied information technology and Internet paraphernalia) bring with them. And, of course, as academics we are alert to our obligation to be "disturbers of the peace" (Passmore, 1967, p. 203) and to "be somewhat reflexive about [our] use of tools, and thus not sound like Microsoft advertising executives" (Rose, 2004, p. 797).

Our discussion is directed to providing a much-needed tempering of the widespread enthusiasm and excitement for PowerPoint while avoiding a seemingly reflexive antitechnology reaction. We seek to engender a clearer appreciation of whether PowerPoint is a beneficial and efficient educational medium by heightening awareness that the technology of PowerPoint is not an "unparalleled conduit of pedagogically related excellence" and that we need an alternative "“attention structure' that does not reify" PowerPoint (Amernic \& Craig, 1999, p. 437).

\section{Is PowerPoint Effective?}

In this section we review the limited empirical evidence on whether or not PowerPoint presentations are effective in enriching student learning. However, we refrain from consideration of such core ideas as critical thinking (Nelson, 1994), the university's role in the communication of imagination (Whitehead, 1957/[1929], p. 97), and learning paradigms for undergraduate education (Barr \& Tagg, 1995). It seems important to review the effectiveness of PowerPoint given its widespread and largely uncritical acceptance, particularly in higher education institutions. This is because, conceivably, PowerPoint might simply lead to a professor's "improvement and/or modernization of their performance in the classroom" (Szabo \& Hastings, 2000, p. 176) without any significant effects on student learning.

Given the widespread adoption of PowerPoint, the small number of authoritative studies of its effectiveness $(n<20)$ is surprising. Generally, the available studies lack substance and internal and external validity and adopt rather constrained characterizations of the concept effectiveness. Most have been conducted in the United Kingdom and the U.S. and involve one-site, cross-sectional analyses of small classes that have been taught by the principal researcher (see, for example, Bartsch \& Cobern, 2003; and the studies reviewed by Szabo \& Hastings, 2000, pp. 176-177). Typically, studies are conducted of classes that have been partitioned into two groups - one taught using lectures and PowerPoint and the other taught using lectures and overhead transparencies. Student attitude responses are gathered usually by means of in-class questionnaire survey methods and need to be scrutinized carefully for unintended bias. 
Other studies are based simply on selective reporting of student anecdotes. Some have a self-indulgent quality of "Hey, look at me, I'm an innovator, and my students like what I am doing." Others are superficial recollections of instructor experience in using PowerPoint (e.g., Parks, 1999). Many studies of student attitudes were conducted before PowerPoint became an ingrained, almost compulsory feature of university lectures. It would not be surprising if many reported results were influenced by a now defunct "novelty factor." With the passage of time and with heightened exposure to PowerPoint, our recent conversations with students suggest they are now more likely to respond to PowerPoint with an air of resigned, nonchalant ennui.

In the main, the results reported in scholarly journal articles indicate that students like to be taught using PowerPoint (perhaps because of its novelty and the availability of printed handouts of PowerPoint slides) and think that PowerPoint presentations are entertaining, enhance clarity, and aid recall of subject matter. There is little consistent evidence, however, to show that teaching with PowerPoint leads to significantly better learning and significantly better grades than teaching by more conventional methods. A majority of studies shows that use of PowerPoint is not associated with a significant improvement in student grades. For example, Rankin and Hoaas (2001) examined the effect of PowerPoint presentations on student grades in four classes of students in an introductory economics course taught by one instructor, at one institution, in two semesters. "Each semester one group of students was taught using PowerPoint slides and the other taught without slides to serve as a control group ...[but there was] ...no significant effect in terms of student performance" (p. 113). Results such as this seem curious in view of the speed and conviction with which PowerPoint has been embraced by educators.

Some other empirical studies are more generous, but are unpublished and unreviewed (e.g., Evans, 1998), or have significant methodological problems (e.g., Harknett \& Cobane, 1997), or have untested assumptions (e.g., Lowry, 1999). Generally, the results of these studies point to the benefits of PowerPoint on student performance. For example, Lowry (1999) concluded that classes taught using PowerPoint "achieved better grades than the traditional-lecture cohort (51.8 and 51.9 versus $43.5 \%$ ) ... and students exposed to PowerPoint lecturing had a positive attitude towards the method" (pp. 20-21).

Bartsch and Cobern (2003, p. 78) provided the following good review of empirical evidence regarding the effectiveness of PowerPoint and computer presentations:

Overall research indicates that students prefer PowerPoint type presentations from transparencies (Cassady, 1998; Perry \& Perry, 1998; Susskind \& Gurien, 1999; West, 1997). Unfortunately, information on whether computer presentations improve student performance is much less clear. Several studies point to the idea that graphics improve student recall (ChanLin, 1998, 2000; Lowry, 1999; Szabo \& Hastings, 2000, Exp. 2). However, many courses that adopted multimedia presentations have not shown a corresponding increase in student performance (Stoloff, 1995; Susskind \& Gurien, 1999; Szabo \& Hastings, 2000. Exp. 1 and 3; West, 1997). In fact, one study demonstrated a decrease in student performance when the instructor switched from transparencies to PowerPoint (Bartlett, Cheng, \& Strough, 2000).

In the study by Szabo and Hastings (2000), over 90\% of students said that PowerPoint "is more attention capturing than the traditional method of lecturing," and 85\% found "PowerPoint lectures are more interesting than traditional lectures" (p. 179). They concluded that:

PowerPoint lectures, at least in some circumstances, mainly add to the entertainment rather than to the education of the students ... Apart from possible benefits on recall, 
no significant advantages to PowerPoint lecturing were found ... students like PowerPoint as a lecturing method. Their preference for PowerPoint lectures, in contrast to their beliefs, is not accompanied by better academic performance (p. 186).

Although students found PowerPoint entertaining, Szabo and Hastings (2000) noted aptly that "the challenge in the new millennium is not to entertain students ... but to improve or to facilitate learning" (p. 187). Such an improvement will not come easily if Parker (2001) is to be believed. He contended that presenters are concentrating more on "formatting slides - because it's more fun to do than concentrate on what [they're] going to say" (Parker, 2001, p. 5). A major challenge facing educators will be to convert the generally positive disposition of students to PowerPoint into significantly better learning and performance.

\section{The Dynamics of the Pedagogical Setting}

It is important to reflect upon the epistemology of our pedagogy. We live in a pedagogic realm in which the lecture has been regarded as "an accomplishment — bringing together a very particular constellation of speaker, space, technology, audience and attention" (Crang, 2003 , p. 242). In the lecture setting, the social roles, expectations, and power relations at play merit our reflection. The encompassing "performative aspects" of PowerPoint and how they "lend authority to the speaker" (Driver, 2003, p. 229) are deserving of reflection too.

Accordingly, we now explore three aspects of the interaction between PowerPoint technology and its "spaces and audiences" (Driver, 2003, p. 229) - first, whether or not PowerPoint serves as a crutch for many presenters, and second, whether or not it has a bad effect on the message by becoming "a tool to separate the presenter from the audience and the message" (Coursey, 2003, para. 5). Third, we also explore the thesis that the visuality of PowerPoint presentations (which should enrich the message) is becoming THE message and that less of an audience's attention is being applied to a speaker's discussion of relevant content (DuFrene \& Lehman, 2004, p. 84).

There are divergent views about whether the teacher or presenter using PowerPoint is still the main actor and a Socratic-type figure in a learning play. One view is that "PowerPoint is teacher-centred. It puts the instructor at the center of the action" (Creed, 1997). As such, (s)he is a narrator tasked with framing the message or performance, both literally and perceptually. Opposed to this, is the view that the use of PowerPoint has reduced the role of the presenter to that of a stagehand (Blokzijl \& Naeff, 2004) in which (s)he has been "effaced" by the visuality of the PowerPoint slide show (Crang, 2003, p. 243). Consistent with this view, the role of the lecturer or presenter has changed: (s)he is a necessary, but annoying distraction, providing Muzak accompaniment to the lecture by means of an often "disembodied voice" (Crang, 2003, p. 243). Indeed, Nunberg (1999, p. 330) drew attention to the argument that the presenter is no longer needed because PowerPoint slides "have begun to take on a life of their own, as if they no longer needed talking heads to speak for them." In this vein, Tufte (2003a) argued that "rather than supplementing a presentation, [PowerPoint] has become a substitute for it" (p. 3).

Our view is that whether a PowerPoint presenter is the centre of attention or more of a stagehand will be a function of the communication ability of the presenter. Good presenters will most likely still be the centre of attention, using PowerPoint appropriately as a valuable communication aid to buttress their rhetoric. Poor presenters, such as nervous freshman students making their first assessable class presentation, will most likely be stagehands, with PowerPoint used as a dominating prop and their visual presence barely discernible. 
What are the implications of interposing a PowerPoint presentation between an instructor and students? When we taught without PowerPoint or led a case discussion without PowerPoint or acted Socratic-like without PowerPoint, our relationship with students was unmediated and more human, more direct, less pre-meditated and less structured. The pedagogy involved depended on the particular situation, the process of interchange, the verbal and nonverbal communication, the repartee, the facial expressions, and the multitude of things that unfold during unmediated human relationships and dialogue. These are all "immediacy behaviours" which include such non-verbal actions as "eye contact, smiling, movement, adopting relaxed body positions, vocal expressiveness" and have been found to have a positive effect on student learning (see Hartnett, Römcke, \& Yap, 2003, p. 315). But when we subcontract our teaching to PowerPoint presentations, often we cannot see the faces of students. The ambient light is often low, and the focus of students is on the PowerPoint screen. It is not as easy to engage in effective "immediacy behaviours" with students, person-to-person, and to interest them vitally in the pursuit of knowledge.

Are educators at risk of falling into Freire's (1993) "banking education" trap by implicitly regarding education as an activity in which students simply withdraw dollops of something called "knowledge" in much the same way that money is withdrawn from a bank account? As a community of educators and students, are we acquiescing to an unthinking acceptance of PowerPoint's imposition of a conduit metaphor to frame (educational) communication in a way in which "language transfers thought to others" using words as a conduit (Reddy, 1993, p. 167)? However, note that Reddy (1993) also cautioned that considering communication as a conduit metaphor "is leading us down a technological and social blind alley. That blind alley is mass communications systems coupled with mass neglect of the internal, human systems responsible for nine-tenths of the work in communicating" (p. 188). In this article we do not pursue the possible connection between the widespread deployment of PowerPoint in education and the implicit framing of educational communication by the conduit metaphor, but, at least according to Reddy, this merits further study.

What do we do if an unplanned, yet fruitful, discussion demands that a PowerPoint presentation be stopped dead in its tracks? Can we allow conversation and discussion to meander down a road with no known ultimate destination? Is it possible to ever discontinue a PowerPoint presentation or, in the best tradition of the theatre, must the "show go on?" Must a pre-planned schedule be followed rigidly because of an unwritten convention of PowerPoint that "no matter what, get through all the slides." Or perhaps, even more chillingly, has the PowerPoint slideshow become the curriculum?

\section{Rhetorical Elements}

Teachers, public speakers, and business seminar presenters are rhetoricians, engaged in acts of persuasion: they seek to persuade or to educate, and to use PowerPoint as a visual aid to make "the logical structure of an argument more transparent" (Parker, 2001, citing Massachusetts Institute of Technology professor of psychology, Steven Pinker, p. 6). Yet the knowledge most have of how to use PowerPoint effectively extends little beyond the general guidelines for using visual aids that have been outlined by Berko, Wolvin and Ray (1997) and Andrews and Baird (2000). Few lecturers or business seminar presenters seem adept at melding their verbal oratory with "visuality as an element of rhetorical invention" (Cyphert, 2004, p. 81). And, as pointed out by Parker (2001), "instead of human contact" PowerPoint gives us a "human display ... we present to each other, instead of 
discussing" (p. 5, italics added). We exacerbate this problem by committing the "sin of triple delivery, where precisely the same text is seen on the screen, spoken aloud, and printed on the handout in front of you" (Parker, 2001, p. 5).

There is a strong argument that the problems of PowerPoint arise from the contempt of many presenters for fundamental rhetorical principles and from their failure to ask such questions: "What does my audience need to know? What point am I trying to make? How do I make that point clearly, thoroughly, transparently? And is the organization of information effective for making my point clear and understandable?" (Shwom \& Keller, 2003 , p. 4). Those who overlook these principles deserve "banishing into the wilderness of incoherence [because they] often lose their way in a thicket of points and sub-points [and compel a reader to] work too hard to decipher meaning" (Shwom \& Keller, 2003, pp. 4-5). One key rhetorical principle was proposed by Shwom and Keller (2003) for following by PowerPoint authors:

On each bullet point slide ... address only one main idea: a single discrete category with sub-items consistently related to that category. Do not use bullet points to present a sequence of ideas. In other words, use bullets to present inductive reasoning, not deductive reasoning (p. 8).

Additionally, many PowerPoint presenters fail to appreciate how rhetorical culture has been changed by PowerPoint communication. According to Cyphert (2005):

The whole notion of having a linear outline is actually a holdover from some pretty traditional-some would say archaic or even xenophobic-rhetorical presumptions. The sad thing is that PowerPoint offers tremendous tools for a speaker, but very, very few get past those dad-gummed bullet points. (response to question 10).

The linearity of PowerPoint and its pesky bullet points hold the prospect of seeming "too slow and boring to students used to MTV, instant messaging and MP3s" (Delaney, 2005, p. R4, citing Tom Wilson, a technology-integration specialist at Hopkins High School, Minnetonka, Minnesota). Indeed, it suggests that Reddy's (1993) conduit metaphor has been given new breath by PowerPoint and is alive and well.

\section{Metaphor}

The metaphors that are associated with the use of PowerPoint merit reflection because the stance educators adopt with regard to the advantages and disadvantages of PowerPoint probably reflect the metaphors that imperceptibly fashion their attitudes. In assessing the way to use PowerPoint, it is important for educators to contemplate the fundamental metaphors that define their approach to teaching. We can identify four major metaphors that influence the way faculty members conceive teaching, by drawing on Fox (1983) and Lucas (2002). These are described in Amernic and Craig (2004, p. 357) as:

- the transfer conception: knowledge is a commodity to be transferred from one vessel to another, a concept consistent with Reddy's conduit metaphor (1993);

- the shaping conception: teaching is usually directed to developing the minds of students;

- the travelling conception: the teacher leads students into new territory and, in doing so, gains new perspectives, too; and

- the growing conception: the teacher is a nurturer. 
Most users of PowerPoint appear to conceive their goals as educators to involve merely a one-way transmission of knowledge, rather than to promote the construction of knowledge and the analysis and synthesis of knowledge (Ramsden, 1992). This transfer, transportation, or conduit model of communication seems to fashion thinking by educators about PowerPoint: they conceive PowerPoint presentations as moving meaning across space in a way in which "the delivery, as opposed to the formulation of meaning" (Angus, 1998 , p. 21) is regarded as most important.

A major pedagogical issue with PowerPoint presentations is that receivers are "passively engaged" rather than "actively engaged." Jones (2003) discussed the danger of making PowerPoint presentations available to students. Such practice is said to encourage "students to sit passively through the session since they may perceive they have 'got the notes'" (p. 5). Tufte $(2003 \mathrm{~b})$ outlined the problems involved very strongly. They are summarized by Simons (2005) as follows:

It [PowerPoint] locks presenters into a linear, slide-by-slide format that discourages free association and creative thinking. It imposes artificial and potentially misleading hierarchies on information ... breaks information and data into fragments, making it more difficult to see the logical relationships between different sets of data. It encourages over-simplification by asking presenters to summarize key concepts in as few words as possible - e.g., bullet points - which can lead to gross generalizations, imprecise logic, superficial reasoning and, quite often, misleading conclusions. It imposes an authoritarian presenter/audience relationship rather than facilitating a giveand-take exchange of ideas and information. (p.5)

Some might argue that Tufte's case is exaggerated, that PowerPoint presentations can be paused for "contemplative effect, and they can serve as a springboard for conversation" (Cyphert, 2005, question 13). Nonetheless, many PowerPoint presenters seem to embrace the transfer conception of education, in preference to the shaping, travelling, and growing conceptions. "If everyone has set their remarks in stone ahead of time (all using the same templates) then there is little room for comments of one to build upon another, or for a new idea to arise collaboratively ... Homogeneity is great for milk, but not for ideas" (Norvig, 2003, p. 344). Educators using PowerPoint should give greater emphasis to working as partners with students, in designing learning activities with them, so that they encourage students to identify new ways of thinking for themselves. Most importantly, therefore, educators should reflect upon the explicit and implicit metaphors that help form the foundation of the cognitive world that is drawn upon in their use of PowerPoint.

\section{PowerPoint Culture}

In this section we examine three aspects of the "PowerPoint culture" in contemporary higher education institutions: power and ideology, cognition and psychology, and production influences.

\section{Power and Ideology}

What is the power of PowerPoint? This is an important question. The extent to which a PowerPoint presenter is in a position of power is often underestimated. Rose (2003, p. 218, 2004) outlined five reasons why, in displaying slides, an academic has the potential to be a "powerful producer of knowledge." 
First, classes are given in spaces, such as lecture halls, that "encourage the practice of attention ... and in which attention is demanded" (Rose, 2003, p. 218). We see this in the strong social convention governing audiences at PowerPoint presentations - to focus attention forward at the video screen and be quiet. Second, the display of slides is a powerful activity. Slides are often shown embedded in a luminescent square of light, surrounded by darkness. This seems to disallow any discussion of their truth status - and it privileges them by imposing a well-demarcated frame. Third, there is also a redirecting of the traditional flow of discourse in the lecture: the speaker "often seems compelled to turn towards the screen and to talk to the projection rather than to the audience" (Rose 2003, p. 215). Fourth, slides "usually work to bestow authority on their expositor ... [who] mediates between the audience and the image by explaining it to them, and the apparent truth of the [slide] produces a truth-effect in the [expositor's] words as well" (Rose, 2003, p. 216). Fifth, PowerPoint presentations "are not shown or seen the same way regardless of where they are screened; the way the [presenter] presents - and their audience views - images differently depend[s] on the location of their display ... [and] the speech and gestures" of the presenter (Rose, 2003, p. 217).

An important aspect is the "visual uniformity" of PowerPoint. This may have ideological associations with the culture of its corporate creator, Microsoft - for example, in the subtle cognitive impacts of the aesthetic layout judgments made in default settings (Matless, 2003).

\section{Cognition and Psychology}

Ideally, lecturers should employ the most effective means to convey their message to students. But research into the effects and effectiveness of PowerPoint technology is rather poor. We are hampered, for example, by an underdeveloped understanding of the level of persuasiveness and psychological impact of PowerPoint as a new visual technology.

A lecture, like a court trial, ought to be regarded as a "search for truth and as a rhetorical contest" (Feigenson \& Dunn, 2003, p. 111). Consequently, there is a strong need for empirical research to address how various PowerPoint presentations have facilitative or prejudicial effects on audiences and how those audiences explain the perceptual, cognitive and emotional reasons for such effects (Feigenson \& Dunn, 2003, pp. 111-112). Currently, PowerPoint presenters have only a rudimentary appreciation of the conditions under which the visual technology they are using helps them to achieve their rhetorical aims.

However, research should focus not just on the visual technology involved. We need to understand also our audience's "perceptual, cognitive, and emotional capabilities, expectations, and habits" and to explore the relationships between audience and "visual technology" and "manipulations of that technology" in a better fashion (Feigenson \& Dunn, 2003, p. 112). In this vein a visual social semiotics approach, involving a study of signs, would help us to understand "how text and images work together to make meaning together for readers/users ... [and to] better understand the rhetorical, meaning-making potential" of PowerPoint presentations and imagery and make them more effective (Harrison, 2003, p. 47). All this underscores the potential cognitive risks for both PowerPoint presenters and PowerPoint presentees. The cognitive world of both educators and students changes, perhaps radically, when PowerPoint becomes the default mode of discourse. We should at least attempt to become aware of the possibilities, both good and not-so-good, that this raises. 


\section{Production Influences}

PowerPoint can be very subverting. Lecturers seem to spend disproportionate amounts of time mesmerized in tinkering with how to present their lecture - agonizing over the choice of design template, color scheme, page layout, and mode of slide transition. That is, they become engrossed in performing the production activities associated with the Microsoft PowerPoint software application rather than concentrate on how they will participate in "uniting the young and the old in the imaginative consideration of learning" (Whitehead, $1957 /[1929]$, p. 93). We need to be alert to the possibility that this production labour effort will interplay with the increasingly hyperactive and mediated demands on university faculty time (e.g., via email and the Internet) to preclude any semblance of a reflective academic life.

\section{Orality, Visuality and Literacy}

PowerPoint should be recognized as a new communication medium that is fundamentally changing the nature and dynamic of how we teach. For over four hundred years, as Postman (1993) noted, teaching settings have been characterized by a fine balance between two forms of learning: orality and the printed word. According to Postman (1993) orality fostered "gregariousness" and stressed "group learning, cooperation, and a sense of social responsibility"; and the printed word fostered "introspection and isolation" and stressed "individualized learning, competition, and personal autonomy" (p.17). Nonetheless, while teachers have tended to emphasize the visuality of print, they "have allowed orality its place in the classroom, and have therefore achieved a kind of pedagogical peace between these two forms of learning, so that what is valuable in each can be maximized" (Postman, 1993, p. 17). What PowerPoint seems to have done is to disturb this pedagogical peace.

Orality, or at least, student-generated orality, seems to have been downgraded by the unidirectional nature of the discourse which accompanies most PowerPoint presentations. That discourse often has the hallmarks of a voice-over accompaniment to a visual display, usually of graphically enhanced printed words. The instructor risks being relegated from a centre stage role, to that of an incidental stagehand.

The use of projection to enhance the visuality of teaching has a long tradition in some disciplines: instructors in geography and art history have used $35 \mathrm{~mm}$ slides for about 100 years (Rose, 2003, 2004). But the visual learning widely believed to be enhanced by PowerPoint seems to assume a false homogeneity: that PowerPoint is an appropriate, effective and amenable aid to learning, irrespective of discipline, learning objectives, and type of learner. For example, the visuality of PowerPoint seems much less likely to be amenable in teaching people to converse in foreign languages.

The form of learning we are gravitating to with PowerPoint is one of televisuality. This may be quite appropriate in the early 21 st century. Young students of the "tech-savvy Play Station 2 generation" (Delaney, 2005, p. R4) will be acculturated to such a mode. Many, if not most, will have been raised in homes bristling with the technology of television, interactive video games, DVD players, computers, and cell phones. The brevity and prevalence of PowerPoint's bullet points, abbreviations, and acronyms will resonate sympathetically with them, as they are likely to be voracious users of cell phone text messaging. Indeed, they would probably even find such use GR8 THK U. (This is commonly used Special Messaging Service [SMS] text for "Great, thank you.") But this all comes at a price - the downgrading of orality and print. 
There is also a profound impact on literacy. PowerPoint slides are often devoid of paragraphs, pronouns, punctuation, conjunctions, auxiliary verbs and articles. The obligation to form full sentences has become optional and the spelling of polysyllabic words has become a lost art in a sea of PowerPoint-induced abbreviations. (A similar criticism could be made of the use of overhead transparency slides. But we contend that the effect is much more pronounced with PowerPoint.) "The world is condensed into a few upbeat slides, with seven or so words on a line, seven lines on a slide" (Parker, 2001, p. 2); and it is "a world where any complex thought must be broken into seven-word chunks, with colorful blobs between them" (Norvig, 2003, p. 343). The use of language is imprecise and deserving of banishment into a "wilderness of incoherence," for it causes audiences to "often lose their way in a thicket of points and sub-points" in "lists gone amuck" (Shwom \& Keller, 2003, pp. 4-5).

Parker (2001, p. 6, citing Nass) argued that PowerPoint "empowers the provider of simple content ... but risks squeezing out the provider of process - that is to say, the rhetorician, the storyteller, the poet, the person whose thoughts cannot be arranged in the shape of a [PowerPoint] slide." Parker (2001) recounted a telling anecdotal confession by Professor Nass about the capacity of PowerPoint to influence curriculum choices:

I hate to admit this but I actually removed a book from my syllabus last year because I couldn't figure out how to PowerPoint it. It's a lovely book called 'Interface Culture,' by Steven Johnson, but it's very discursive; the charm of it is the throwaways. When I read this book, I thought, my head's filled with ideas, and now I've got to write out exactly what those ideas are, and they're not neat. [Parker then observes that Nass] couldn't get the book into bullet points; every time he put something down, he realized that it wasn't quite right. Eventually, he abandoned the attempt, and instead of a lecture, he gave his students a recommendation. He told them it was a good book, urged them to read it, and moved on to the next bullet point (p. 6).

PowerPoint also effects how we expose students to a curriculum. Norvig (2003) argued that PowerPoint "makes it harder to have an open exchange between presenter and audience, to convey ideas that do not neatly fit into outline format" (p. 344). And Creed (1997, Classroom assessment) makes several apposite points: first, "You may get less feedback from the class because your eyes and theirs are on the screen rather than looking at each other;" second, students don't have a chance to synthesize what they've heard; and third, the emphasis is on the quality of your presentation rather than your students' learning. Indeed, because of the facility for PowerPoint to be distributed in handout form at the commencement of classes and for PowerPoint presentations to be placed on the Web, students no longer need to listen carefully in class. Indeed, if lecturers simply read their PowerPoint presentations, there seems little point in them attending lectures at all.

\section{Conclusion}

All users of PowerPoint should respond to Postman's (1993) call and pause to reflect about any new technology, such as PowerPoint, and how it affects, however imperceptibly, their engagement with what and how they teach. They should engage in conversations and critique of new technologies, rather than to accept them blithely and unquestioningly.

As a society we should be mindful that PowerPoint, in concert with allied computer and Internet-based technology, is having a profound effect on higher education. PowerPoint is 
not merely a benign means of facilitating what educators have always done. Rather, it is changing much (perhaps most) of how we engage with our students and the disciplines which we profess. We should be curious as to why this is so. We should be eager to understand the assumptions and metaphors that subtly infuse PowerPoint. We should also be more aware of the culture, customs, and behaviour that are dragged along with PowerPoint and how they affect the way we think about our students, our audiences, ourselves, and our disciplines.

\section{References}

Amernic, J. H., \& Craig, R. J. (1999). The internet in undergraduate management education: A concern for neophytes among metaphors. Prometheus, 17, 437-450.

Amernic, J., \& Craig, R. (2004). An agenda for the reform of accounting education in the post-Enron era: Moving accounting 'out of the shadows.' Abacus, 40, 342-378.

Andrews, P. H., \& Baird, J. E. J. (2000). Communication for business and the professions. New York, NY: McGraw-Hill.

Angus, I. (1998). The materiality of expression: Harold Innis' communication theory and the discursive turn in the human sciences. Canadian Journal of Communication, 23, 9-29.

Barr, R. B., \& Tagg, J. (1995). From teaching to learning: A new paradigm for undergraduate education. Change, 13-25 Nov/Dec.

Bartlett, R. M., Cheng, S., \& Strough, J. (2000). Multimedia versus traditional course instruction in undergraduate introductory psychology. Poster presentation, Annual Conference of the American Psychological Association, Washington, DC.

Bartsch, R. A., \& Cobern, K. M. (2003). Effectiveness of PowerPoint presentations in lectures. Computers and Education, 41, 77-86.

Berko, R., Wolvin, A., \& Ray, R. (1997). Business communication in a changing world. New York, NY: St. Martins.

Blokzijl, W., \& Naeff, R. (2004). The instructor as stagehand: Dutch student responses to PowerPoint. Business Communication Quarterly, 67, 70-77.

Bostock, S. (2005). Using PowerPoint for Teaching. Retrieved on January 19, 2005 from www.keele.ac.uk/ depts/cs/Stephen_Bostock/talwt/materials/powerpoint-for-teaching.ppt.

Cassady, J. C. (1998). Student and instructor perceptions of the efficacy of computer-aided lectures in undergraduate university courses. Journal of Educational Computing Research, 19, 175-189.

ChanLin, L.-J. (1998). Animation to teach students of different knowledge levels. Journal of Instructional Psychology, 25, 166-175.

ChanLin, L.-J. (2000). Attributes of animation for learning scientific knowledge. Journal of Instructional Psychology, 27, 228-238.

Coursey, D. (2003, September 10). What's wrong with PowerPoint-And how to fix it? AnchorDesk. Retrieved December 8, 2004 from http://www.zdnet.com/anchordesk/stroies/story/o,10738,2914637,00.hml.

Crang, M. (2003). The hair in the gate: Visuality and geographical knowledge. Antipode, 35, $238-243$.

Creed, T. (1997, May). PowerPoint, No! Cyberspace, Yes. The National Teaching and Learning Forum, 6 , (4). Retrieved January 4, 2005 from http://www.ntlf.com/html/pi/9705/creed 1.htm.

Cyphert, D. (2005). A clash of rhetorical cultures: Q \& A with Dale Cyphert, Ph.D. Retrieved on January 3, 2005 from www.sociablemedia.com.

Cyphert, D. (2004). The problems of PowerPoint: Visual aid or visual rhetoric? Business Communication Quarterly, 67, 80-83.

Delaney, K. (2005, January 17, p. R4.). Teaching Tools: How do you communicate with students who have grown up with technology? Schools are looking to technology for the answer. The Wall Street Journal. Retrieved on January 18, 2005 from http://proquest.umi.com/.

Driver, F. (2003). On geography as a visual discipline. Antipode, 35, 227-231.

DuFrene, D. D., \& Lehman, C. M. (2004). Concept, content, construction, and contingencies: Getting the horse before the PowerPoint cart. Business Communication Quarterly, 67, 84-88.

Evans, L. (1998). Preliminary study: Lectures versus PowerPoint 4.0. Retrieved on January 4, 2005 from http://www.kcmetro.cc.mo.us/longview/lect_ppt.HTM.

Feigenson, N., \& Dunn, M. A. (2003). New visual technologies in court: Directions for research. Law and Human Behavior, 27, 109-126. 
Fox, D. (1983). Personal theories of teaching. Studies in Higher Education, 8, 151-163.

Freire, P. (1993). Pedagogy of the oppressed (M. B. Ramos, Trans.). New York, NY: Continuum (Original work published 1972).

Goldkorn, J. (2004, October). The curse of PowerPoint. That's Beijing. Retrieved on December 8, 2004 from www.thatsmagazines.com/features.index.asp.

Harknett, R. J., \& Cobane, C. T. (1997). Introducing instructional technology to international relations. Political Science and Politics, 30, 496-500.

Hartnett, N., Römcke, J., \& Yap, C. (2003). Recognizing the importance of instruction style to students' performance: Some observations from laboratory research-A research note. Accounting Education, 12, 313-331.

Harrison, C. (2003). Understanding how still images make meaning. Technical Communication, 50, 46-60.

Innis, H. A. (1991). The bias of communication. Toronto, ON, Canada: University of Toronto Press.

Jones, A. M. (2003). The use and abuse of PowerPoint in teaching and learning in the life sciences: A personal view. BEE-j 2. Retrieved on February 23, 2006 from http://www.bioscience.heacademy.ac.uk/ journal/vol2/beej-2-3.pdf.

Lanham, R. (1993). The electronic word. Chicago, IL: University of Chicago Press.

Lowry, R. B. (1999). Electronic presentation of lectures-Effect upon student performance. University Chemistry Education, 3, 18-21.

Lucas, U. (2002). Contradictions and uncertainties: Lecturers' conceptions of teaching introductory accounting. British Accounting Review, 34, 183-203.

Matless, D. (2003). Gestures around the visual. Antipode, 35, 222-226.

McLuhan, M., \& Fiore, Q. (1967). The medium is the message. New York, NY: Random House.

Nelson, C. E. (1994). Critical thinking and collaborative learning. New Directions for Teaching and Learning, 59, 45-58 San Francisco, CA: Jossey-Bass.

Norvig, P. (2003, August 2). PowerPoint: Shot with its own bullets. The Lancet, 362, 343-344.

Nunberg, G. (1999, December 20). The trouble with PowerPoint. Fortune, 330-331.

Parker, I. (2001, May 28). Absolute PowerPoint. The New Yorker, 77 (13), 76-87. Retrieved on January 10, 2005 from http://polyglot.lss.wisc.edu/lss/intime/AbsolutePPT.pdf, 1-6.

Parks, R. P. (1999). Macro principles, PowerPoint, and the internet: Four years of the good, the bad, and the ugly. Journal of Economic Education, 30, 200-209.

Passmore, J. (1967). On teaching to be critical. In R. S. Peters, (Ed.), The concept of education (pp. 192212). London, England: Routledge, Kegan Paul.

Perry, T., \& Perry, L. A. (1998). University students' attitudes towards multimedia presentations. British Journal of Educational Technology, 29, 375-377.

Postman, N. (1993). Technopoly: The surrender of culture to technology. New York, NY: Random House.

Ramsden, P. (1992). Learning to teach in higher education. London, England: Routledge.

Rankin, E. L., \& Hoaas, D. J. (2001). The use of PowerPoint and student performance. Atlantic Economic Journal, 29, 113.

Reddy, M. J. (1993). The conduit metaphor: A case of frame conflict in our language about language. In A. Ortony (Ed.), Metaphor and thought (pp. 164-201). Cambridge, England and New York, NY: Cambridge University Press.

Rose, G. (2003). On the need to ask how, exactly, is geography 'visual?' Antipode, 35, 212-221.

Rose, G. (2004). On the importance of asking the right questions, or what is the power of PowerPoint, exactly? Antipode, 36, 795-797.

Shwom, B. L., \& Keller, K. P. (2003). The great man has spoken. Now what do I do? A response to Edward R. Tufte's "The cognitive style of PowerPoint." Communication Insight, 1, 1-15. Retrieved on December 17, 2004 from www.communipartners.com.

Simons, T. (2005). Does PowerPoint make you stupid? Presentations, 18 (3). Retrieved on November 21, 2005 from http://g;lobal.factiva.com/.

Stewart, T. A. (2001, February 5). Ban it now! Friends don't let friends use PowerPoint. Fortune, 143, 210.

Stoloff, M. (1995). Teaching physiological psychology in a multimedia classroom. Teaching of Psychology, $22,138-141$.

Susskind, J., \& Gurien, R. A. (1999). Do computer-generated presentations influence psychology students' learning and motivation to succeed? Poster session, annual convention of the American Psychological Society, Denver.

Szabo, A., \& Hastings, N. (2000). Using IT in the undergraduate classroom. Should we replace the blackboard with PowerPoint? Computers and Education, 35, 175-187.

Tufte, E. R. (2003a, September). PowerPoint is Evil. Wired. Retrieved on December 8, 2004 from http:// www.wired.com/wired/archive/11.09/ppt2.html.

Tufte, E. R. (2003b). The cognitive style of PowerPoint. Cheshire, CT: Graphics. 
Van Jole, F. (2000, November). Het PowerPoint denken. FEM Ide Week. Retrieved on February 23, 2006 from http://www.2525.com/archive2/020928.html.

Warnick, B. (2002). Analogues to argument: New media and literacy in a posthuman era. Argumentation and Advocacy, 38, 262-270.

West, R. L. (1997). Multimedia presentations in large classes: A field experiment. Paper presented at the Annual Convention of the American Psychological Society, Washington, DC.

Whitehead A. N. 1957/[1929]. The aims of education and other essays. New York, NY: Free Press. 